\title{
Historical High Complexity Neurosurgery Development of One of the Poorest Brazilian Regions
}

\section{Desenvolvimento histórico de neurocirurgia de alta complexidade de uma das regiões mais pobres do Brasil}

\author{
Silvio Pereira Ramos Junior ${ }^{1, *(1)}$ Bruno Bastos Godoi ${ }^{2, *}$ \\ Sebastião Nataniel Silva Gusmão ${ }^{3}$ (1) \\ ${ }^{1}$ Division of Neurology and Neurosurgery, School of Medicine, \\ Universidade Federal dos Vales do Jequitinhonha e Mucuri, \\ Diamantina, MG, Brazil \\ 2 School of Medicine, Universidade Federal dos Vales do Jequitinhonha \\ e Mucuri, Diamantina, MG, Brazil \\ 3 Division of Neurosurgery, School of Medicine, Universidade Federal \\ de Minas Gerais, Belo Horizonte, MG, Brazil
}

\author{
Patrício Jesus Cordeiro ${ }^{2}$ Jorge Diniz Neto ${ }^{2}$ J
}

\begin{abstract}
Address for correspondence Bruno Bastos Godoi, Rodovia MGT 367, Km 583, 5000, Alto da Jacuba, Diamantina, MG, 39100-000, Brazil (e-mail: bastosgodoi@gmail.com).
\end{abstract}

Arq Bras Neurocir 2020;39(3):197-200.

\section{Abstract \\ Keywords \\ - history \\ - faculty \\ - medical schools \\ - neurosurgery}

\section{Resumo}

Human development rates in the Vale do Jequitinhonha, state of Minas Gerais, Brazil, called "Misery Valley," are among the lowest in the country, not to mention the often precarious psychosocial realities that daily contact with these families reveals. The history of neurosurgery at the Neurosurgical Reference Center at the Vale do Jequitinhonha e Mucuri dates from 2004, when the first neurosurgical procedures were performed in the recently organized Section of Neurosurgery. The historical surgical series shows the positive impact of the service. In 2007, the average was 3 neurosurgeries/month. In the last year, 2018, service growth boosted the record to 34.83 neurosurgeries/month. In addition to performing elective surgery, the neurosurgery team supports the emergency team by performing some neurosurgical procedures. The service number of patients operated since the development of the service is nearly 3,000. Neurosurgery at the Santa Casa de Caridade from Diamantina has been made comparable to the best national neurosurgery services.

As taxas de desenvolvimento humano no Vale do Jequitinhonha, Minas Gerais, Brasil, denominado "Vale da Miséria," estão entre as mais baixas do país, sem mencionar as realidades psicossociais, muitas vezes precárias, que o contato diário com essas famílias revela. A história da neurocirurgia no Centro de Referência Neurocirúrgica do Vale do Jequitinhonha e Mucuri vem de 2004, quando os primeiros procedimentos neurocirúrgicos foram realizados na recém-organizada Seção de Neurocirurgia. A série

These authors did the same work.

received

December 21, 2019

accepted

May 12, 2020
DOI https://doi.org/

10.1055/s-0040-1713920. ISSN 0103-5355.
Copyright $(2020$ by Thieme Revinter

Publicações Ltda, Rio de Janeiro, Brazil
License terms

(c) $(1) \$$ 
Palavras-chave

- história

- faculdade

- faculdades de medicina

- neurocirurgia histórica de cirurgias mostra o impacto positivo do serviço. Em 2007, a média foi de 3 neurocirurgias/mês. No último ano de 2018, o crescimento do serviço elevou o recorde para 34,83 neurocirurgias/mês. Além de realizar cirurgias eletivas, a equipe de neurocirurgia apoia a equipe de emergência executando alguns procedimentos neurocirúrgicos. O número de pacientes operados desde o desenvolvimento do serviço é de $\sim 3,000$. A neurocirurgia na Santa Casa de Caridade de Diamantina foi comparada aos melhores serviços nacionais de neurocirurgia.

\section{Introduction}

Neurosurgery is one of the most specific medical clusters, whose professionals treat many neurological disorders, like brain tumors, brain trauma injury, spinal cord injury, as other neurosurgery issues. After medicine graduation, neurosurgery residents have to pass through 5 years of training to graduate as a neurosurgeon, and after that have to exercise more than 3,000 hours in an operative room to occupy the place of experienced neurosurgeon. ${ }^{1-4}$

\section{Brazilian Neurosurgery: A Brief History}

In Brazil, neurosurgery emerged from Luis Gomes Ferreyra, a doctor born in Portugal who practiced medicine in Sabará and Vila Rica (Ouro Preto, nowadays), who performed the first known neurological surgery procedure in Brazil, in 1710 , at a little town located in the countryside of Minas Gerais state (Sabará city). The patient was a slave who presented a brain trauma injury after a falling from a tree branch. Seeing this, Luis Gomes Ferreyra removed the fractured bone fragments and covered the bone defect with a piece of calabash shell until bone healing occurred. After that, the patient returned to work with a mild sequela, characterized as an expressive dysphasia. ${ }^{5,6}$ Brandão Filho was a general surgeon interested in brain surgery. In 1924, he performed the first ventriculography in Brazil, and in 1928 he performed America's first cerebral angiography. Despite the first performed neurosurgery procedure in 1710, Brazilian neurosurgery just grew up from 1928 with two general surgeons: Alfredo Monteiro and José Ribes Portugal..$^{5-8}$

\section{Neurosurgery Assessment Countrywide}

Brazilian neurosurgery has increased in number as also in complexity and worldwide visibility. Nevertheless, according to the National Registry of Health Facilities, in 2018, there were almost 1,200 neurosurgeons in the whole national territory. It shows a small number of professionals to attend plenty of neurosurgical diseases. Furthermore, the majority of these professionals are allocated in the Southern region, one of the more prosperous regions of the country. ${ }^{9}$ The primary health system in Brazil is the Brazilian Unified Health System (SUS, in the Portuguese acronym), which is one of the largest public health care systems in the world and provides a wide range of services, including neurosurgery services, divided into two groups: high-complexity assistance units (HCAUs) and high-complexity neurosurgical reference centers (HCNRCs). ${ }^{5,6,10}$ The first one is characterized as hospital units that have technical conditions and human resources available to assist those patients that require high-complexity neurointervention and neurosurgical procedures. ${ }^{3-8,10,11}$

\section{High-complexity Neurosurgical Reference Center Development at the Vale do Jequitinhonha e Mucuri}

Human development rates at the Vale do Jequitinhonha e Mucuri region (called "Misery Valley") are among the lowest in the country, not to mention the often poor psychosocial realities that daily contact with these families reveals.

In Diamantina, allocated at the Vale do Jequitinhonha e Mucuri region, with a predicted population of 50,000 inhabitants, one of the unique High-complexity Neurosurgical Reference Center was developed in a county with $<100,000$ inhabitants. Although Diamantina is in Minas Gerais, Brazil's southeastern region, the wealthiest region countrywide, it remains with poor health access and low economical rates. This situation explains the history question of Diamantina and the whole Vale do Jequitinhonha e Mucuri region. The Jequitinhonha that we have today still suffers the consequences of the colonization process and slavery. Diamantina still has some difficulties at health access from some counties due to the distance or even the shortage of transport to bring those patients with neurosurgical issues.

Transport logistics from patients to Diamantina are highly complex. Individuals with a variety of neurological sequelae often have to leave the house on foot or on the back of an animal at dawn to be able to overcome the arduous stages to the outpatient clinics in the late afternoon. Such a situation significantly increases the chances of prehospital complications of trauma and other neurological disorders, for apparent reasons. All of these factors further expand the need for a systematically humanized approach to these poor Brazilians and become a powerful enabler for dealing with delicate medical situations.

The Santa Casa de Caridade de Diamantina is an institution almost entirely funded by the SUS. About $90 \%$ of the patients treated at the hospital are SUS users, and virtually all improvements in their physical structure, guaranteed by funds from the Ministry of Health, which are invariably honestly allocated.

Particularities of the scenario demonstrate the consent of the political entities by our work philosophy. Diamantina, whose estimated population in 2010 was 45,884 inhabitants, 
is the only Brazilian city with $<150,000$ inhabitants to have a SUS-accredited High Complexity Neurosurgery service. For the perfect functioning of such a service, the availability of state-of-the-art diagnostic tests is indispensable. At the Santa Casa de Diamantina, in partnership with the private sector, a state-of-the-art Netherland magnetic resonance imaging (MRI) (Philips Achieva 1.5T MRI, GE Health Care, Best, The Netherlands) equipment is in operation, which has enabled the rapid and accurate diagnosis and optimal treatment of the most diverse pathologies of the nervous system. This equipment is the only one in Brazil, in cities with a population of $<100,000$ inhabitants, which has accreditation to perform examinations by the SUS.

Moreover, technological resources are available, some unusual in public services, such as:

- Zeiss OPMI Vario/S88 operating microscope (Jena, Germany);

- Aesculape pneumatic craniotome (Center Valley, PA, USA);

- Integra Cusa Dissectron ultrasonic cleaner (Priceton, USA);

- Aesculape Neuroendoscope ( Center Valley, PA, USA);

- Micromar stereotaxis kit (Toledo, Spain);

- Micromar Radiofrequency Device (Toledo, Spain);

- General surgical equipment: Philips surgical arch (Best, The Netherlands), articulated electric surgical tables Sismatec and Barrfab (Rio Grande do Sul, Brazil), Dixtal and Takaoka anesthesia machines (São Paulo, Brazil), and Deltronix digital electric scalpels (Ribeirão Preto, Brazil).

Therefore, all neurosurgical patients have full access to Computed Tomography (CT) in the Santa Casa de Caridade de Diamantina. Adding to this, in front of the surgical ward is the Intensive Care Unit (ICU) with 20 beds highly prepared to assist neurosurgical patients and those with other health issues. Services guarantee the coverage of the neuro hemodynamic service in the municipality of Belo Horizonte, capital of the state of Minas Gerais. Patients are referred for diagnostic tests and complicated treatments in neurointervention, such as endovascular obliteration of aneurysms and other cerebral vascular malformations, as well as stent implantation in the cervical and cranial arteries.

The historical series of performed surgeries shows the positive impact of the service (-Fig. 1). In 2007, the average was 3 neurosurgeries/month. In the last year, 2018, the service growth boosted the record to 34.83 neurosurgeries/month, as illustrated in -Fig. 2. These data show that neurosurgical resolution has increased by an impressive $1,000 \%$ since service delivery began 12 years ago.

Far more important than numbers, surgical outcomes have been a constant stimulus to life-saving investments. Morbidity and mortality rates $<5 \%$ are close to those in the international literature, translated into low permanence, minimized costs, and high internal and external customer satisfaction rates.

\section{Emergencies Service}

In addition to performing elective surgery, the neurosurgery team supports the emergency team by performing some neurosurgical procedures (polytraumatized patients and patients with other neurological complaints, signs, or symptoms) and access to ICU, if necessary.

\section{Resolution of the Elective Neurosurgical Demand of the Region}

The team organized the neurosurgical subspecialties among its professionals (oncological and skull base, vascular, endoscopic, spinal, functional, stereotactic, pediatric, peripheral nerve, and neurointervention neurosurgery), achieving continuous and highly specialized improvement. The company

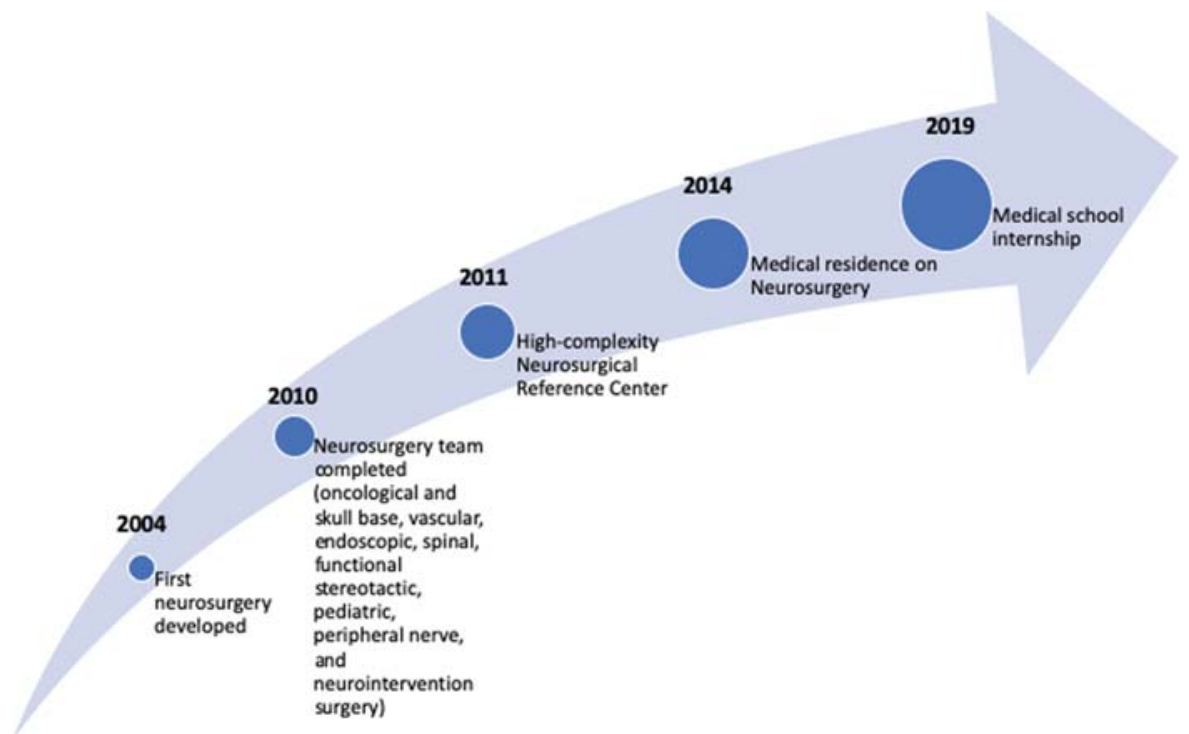

Fig. 1 Timeline of the main events of the neurosurgery service since its foundation. 
600

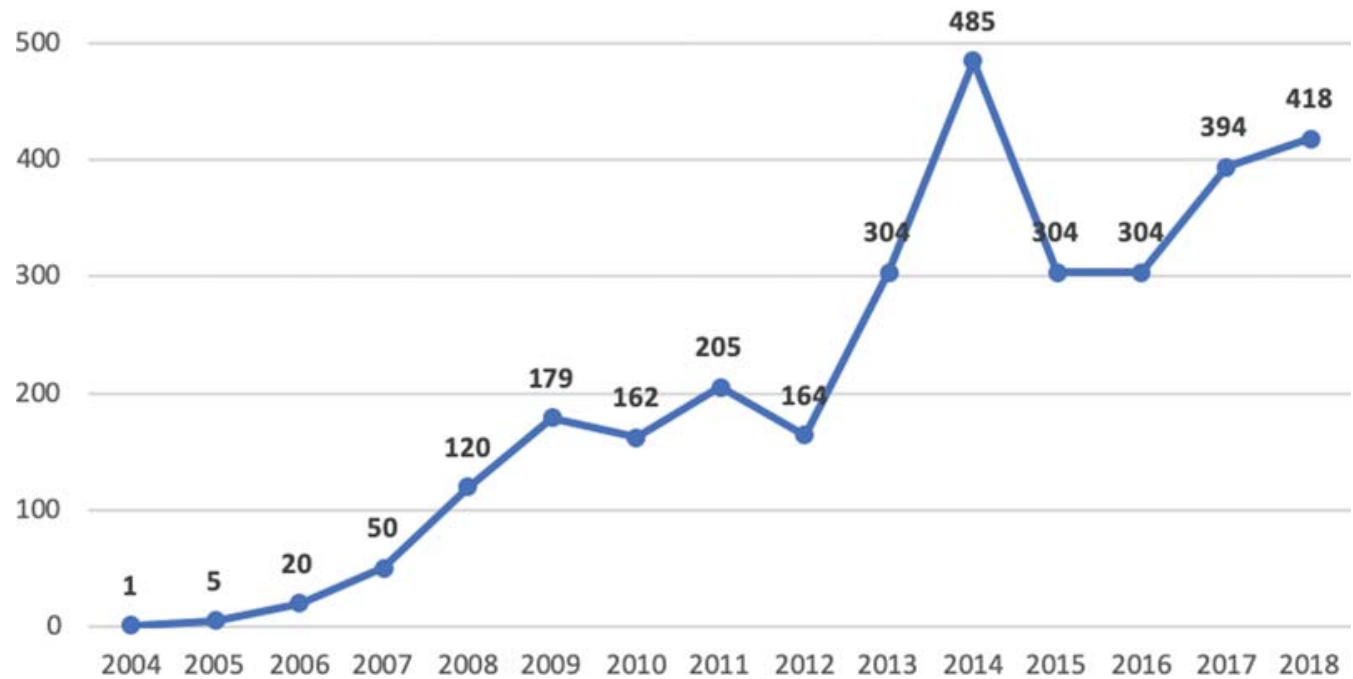

Fig. 2 Number of neurosurgeries since the implementation of the High-complexity Neurosurgical Reference Center at the Vale do Jequitinhonha e Mucuri.

resolves any elective neurosurgical situation in a large and exclusive operating room.

Neurosurgery at the Santa Casa de Caridade de Diamantina has been made comparable to the best national neurosurgery services.

Currently, nearly 3,000 patients have been operated on since the service has been implemented. The service admits one resident a year for training. Nowadays, the discipline of neurosurgery of the Santa Casa de Caridade de Diamantina forms young surgeons who indeed will become some of the future leaders of neurosurgery in Brazil and in the Vale do Jequitinhonha.

\section{References}

1 Gusmão S, Silveira RL, Cabral Filho G. Broca e o nascimento de moderna neurocirurgia. Arq Neuropsiquiatr 2000;58(04):1149-1152

2 Valença MM, da Silva AA, Bordini CA. Headache research and medical practice in Brazil: an historical overview. Headache 2015; 55(Suppl 1):4-31
3 Ausman JI. Achievements of the last century in neurosurgery and a view to the 21st century. Surg Neurol 2000;53(04): 301-302

4 de Mello PA. Neurosurgical training in Brazil. World Neurosurg 2012;77(3-4):422-424

5 de Sousa AA, Dellaretti M. Neurosurgery in Brazil. World Neurosurg 2012;77(3-4):419-421

6 Gusmão S, de Souza J. The Early History of Neurosurgery in Brazil. 2002;50:1336-1345

7 Blakeway M. The early history of neurosurgery in the Transvaal. Adler Mus Bull 2002;28(2-3):6-7

8 Teixeira MJ, Figueiredo EG, Taricco MA, et al. The history of neurosurgery at the University of Sao Paulo. Arq Neuropsiquiatr 2014;72(03):251-253

9 Ministério da Saúde. DATASUS. (2018). Available at: http:// www2.datasus.gov.br/DATASUS/index.php?area=060804.

(Accessed: 5th May 2019)

10 Falavigna A, Canabarro CT, Medeiros GS. Health system and medical education in Brazil: history, principles, and organization. World Neurosurg 2013;80(06):723-727

11 Apuzzo MLJ. Modernity and the emerging futurism in neurosurgery. J Clin Neurosci 2000;7(02):85-87 